\title{
Lina Stern (1878-1968): an outstanding scientist of her time
}

\author{
Levent Sarikcioglu ${ }^{1}$
}

Received: 7 March 2017 / Accepted: 17 March 2017 /Published online: 1 April 2017

(C) Springer-Verlag Berlin Heidelberg 2017

\section{Her life}

Lina Stern (Fig. 1 and cover image) was born in Liepāja, the largest city in the Courland Region situated in western Latvia, on August 26, 1878. She was the eldest of seven children. Due to her Jewish origin, it was too hard for her to gain admission to Russian universities. For this reason, many Jewish students had to fulfill their education abroad [1]. Lina Stern was not the exception among many Jewish scientists. In 1898, Stern embarked on her undergraduate career as a medical student at the University of Geneva. Before her coming to Switzerland, she tried to gain admission to Moscow University [2].

While taking her education, Stern started to work at the Department of Physiology under the supervision of Dr. JeanLouis Prévost (1938-1927). In 1903, Stern received the degree of "Doctor of Medicine" by her doctoral dissertation on motor function of the excised ureter [3]. She returned to her hometown and passed the exams for approval of her doctoral degree according to Russian laws. While preparation to embark on her medical career in Russia, Dr. Jean-Louis Prévost invited her to work as his assistant at the Department of Physiology in Geneva [1]. Dr. Stern immediately accepted this invitation and started to her second scientific journey in Geneva which will be ended her as the first female professor at the Geneva University and head of the Department of Physiological Chemistry [2].

Levent Sarikcioglu

levent@akdeniz.edu.tr; sarikcioglul@gmail.com

1 Department of Anatomy, Akdeniz University Faculty of Medicine, 07070 Antalya, Turkey

\section{Her scientific achievements}

Together with von Frédéric Batelli (Professor of Physiology in Geneva, 1867-1941), Stern published numerous articles on respiratory enzymes, effects of electrical discharge on the heart, central and autonomic nervous system, and physiology of blood [1]. Dr. Stern studied oxidative fermentation by using minced animal tissues containing substances that can transfer hydrogen atoms from specific intracellular organic acids to methylene blue dye, reducing it to a colorless form [4]. Their observations remained isolated observations because they could not be linked to the oxidation of carbohydrate. This link (cellular respiration) was done by Hans Adolf Krebs (1900-1981) in 1937 [5].

She added newly created subject "Physiological chemistry" to the curriculum of the medical faculty. In 1918, a new department "Physiological Chemistry" was established at the University of Geneva, and Dr. Stern became a chaired Professor of the department. She was the first woman to receive the rank of Professor at the University of Geneva $[1,6$, 7].

\section{Barrière hématoencéphalique}

After her appointment as the head of the Department of Physiological Chemistry, Dr. Stern was inspired by her friendship with Constantin von Monakow, and her scientific interest was therefore shifted to the physiology of the central nervous system [8]. From 1918 to 1925, Dr. Stern and her colleague Raymond Gautier (1885-1957) performed numerous experiments by injecting a variety of substances into subarachnoid space, cerebral ventricles, and blood [1]. They injected the substance into blood, and before this injection, they performed nephrectomy in order to avoid any leakage of the substance. 


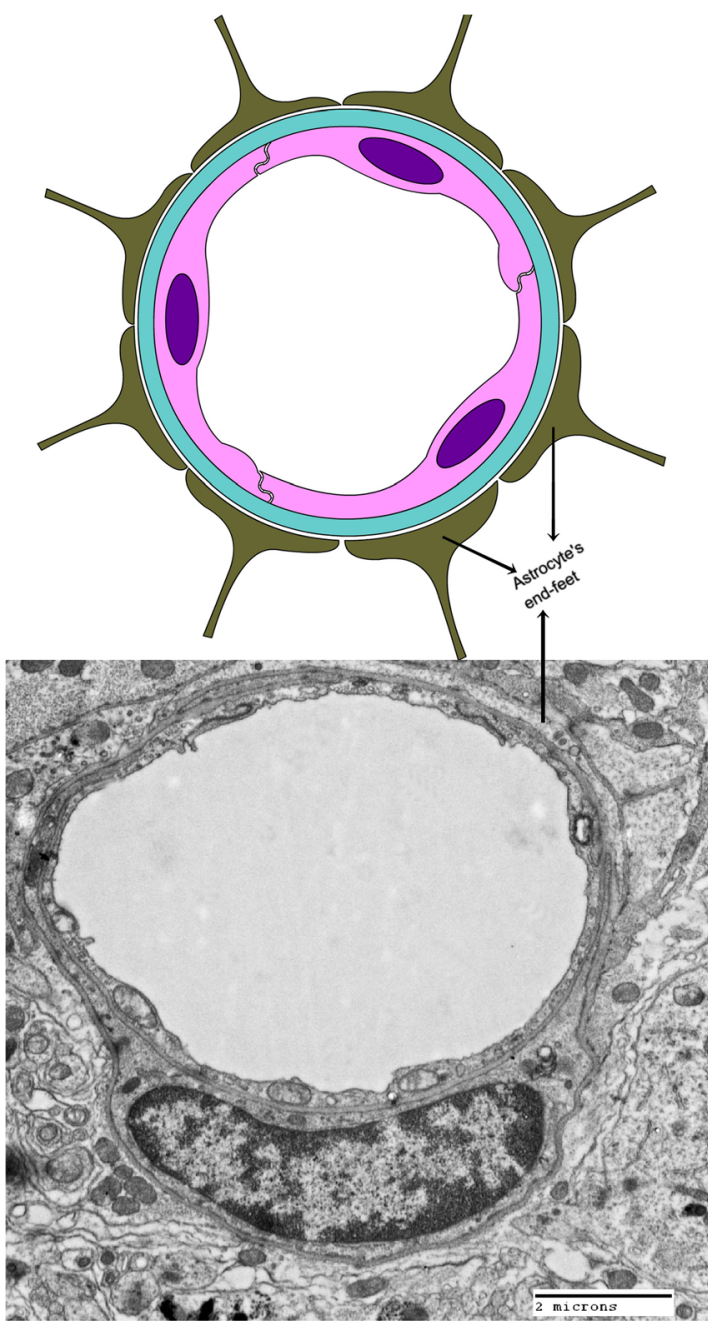

Fig. 1 and cover image Schematic drawing of the blood-brain barrier and photograph of Lina Stern while her attendance to the Ninth International Congress of Psychology, New Haven, Connecticut, USA, September 2-7, 1929 (with permission of the Smithsonian Institution.

After a time, the cerebrospinal fluid was withdrawn and analyzed whether the substance had penetrated or not. Among the substances that could penetrate the barrier were bromide, thiocyanate, strychnine, morphine, atropine, and bile salts, while iodide, ferrocyanide, salicylate, curare, adrenaline, bile pigments, eosin, and fluorescein were said to be invariably absent from the cerebrospinal fluid [9]. On April 21, 1921, Stern introduced the term "Barrière hématoencéphalique" at the Medical Society of Geneva. In the same year, she published her conceptual article on this topic $[10,11]$.

In another set of experiments [12], Stern and Gautier studied to establish a correlation between penetration of some substances into the cerebrospinal fluid and their influence on the nervous system. They performed intravenous injection of bromide in rabbit and found penetration of the bromide in both cerebrospinal fluid and nervous tissue. Those penetrations caused some depressant effects. Similar penetrations were also observed for thiocyanate which increased the excitability of cats. However, iodide and ferrocyanide had no nervous effect and were found to be absent in cerebrospinal fluid and nervous tissue. Contrary to their injection to the blood, characteristic neurological effects, an evidence for their penetration into the brain, were produced when they injected directly into the subarachnoid space [9]. After these experiments, Dr. Stern also demonstrated that immaturity of barrière hématoencéphalique in the developing brain (newborn rats, rabbits, and guinea pigs) [13-15].

\section{Her life in Russia}

After some unsuccessful attempts to get promoted to the full professorship in Geneva, in 1924, she received a letter from Aleksei Nikolaevich Bach (founder of Soviet Biochemistry, 1857-1946) in which she was officially invited to take the vacant position of head of Physiology Department at the 
Second Moscow State University. She did not think twice and immediately accepted this invitation. On March 1925, at the age of 48, Stern arrived in Moscow to hold the vacant position. She continued to her studies in Moscow, organized scientific meeting, invited outstanding scientists to the institute, and published numerous articles [1,2].

In 1929, Dr. Stern founded the Institute of Physiology with the help of the People's Commissariat of Education and People's Commissariat of Health in Moscow [16]. In 1932, she was elected to full membership of the Russian Academy of Sciences; any women had not been awarded before with this reward [1]. In 1939, she was elected a full member of the Academy of Sciences, and the institute became part of the USSR Academy of Science. In the same year, she became a member of the communist party. In 1943, she was awarded the Stalin Prize for her outstanding achievement in the research of the blood-brain barrier [16]. Shortly after the German troops failed to conquer Stalingrad, Dr. Stern was asked to join Jewish antifascist committee (a committee on women, youth, scientists, Slavs, and Jews) which was set up by the Soviet authorities in order to mobilize world Jewish support for the USSR's war effort against Nazi Germany [2, 16]. Jewish antifascist committee was set up on women, youth, scientists, Slavs, and Jews. Lina Stern was associated with the antifascist committees of scientists and women [1].

In 1948, she was expelled from all positions she held in medicine/science and exiled for 5 years in Dzhambul (Kazakhstan). Because, Stern's some cultural connections with Judaism, although she was not religious, were opposite to the policy of Stalin towards the Jews [6], she spent nearly 4 years in prison. In 1952, leading members of Jewish antifascist committee were tried in secret and, all except for Stern, were executed. Shortly after Stalin's death, she returned to Moscow and headed physiology laboratory of the Biophysics Institute of the USSR Academy of Science until her death [16].

Lina Stern died on March 7, 1968 and was buried at the famous Novodevichij cemetery in Moscow. Dr. Stern devoted most of her time to scientific research. She will be remembered for her innovative researches on the nervous system. Although she was humiliated during and after war years, she never discouraged and stopped her scientific studies in biochemistry and neurophysiology.
Acknowledgements The authors thank Akdeniz University Research Project Unit for their support.

Compliance with ethical standards

Conflict of interest The author declares no conflict of interest.

\section{References}

1. Vein AA (2008) Science and fate: Lina Stern (1878-1968), a neurophysiologist and biochemist. J Hist Neurosci 17:195-206

2. Dreifuss JJ, Tikhonov N (2006) The intersection of personal and academic history: Lina Stern (1878-1968). In: Kokowski M (ed) 2nd International Conference of the European Society for the History of Science, Cracow, Poland,

3. Stern L (1903) Contribution à l'étude physiologique des contractions de l'uretère Laboratoire de physiologie. l'Université de Genève, Geneva, pp 1-85

4. Batelli F, Stern L (1912) Die Oxydationsfermente. Ergeb Physiol 12:97-268

5. Krebs H (1953) The citric acid cycle: Nobel Lecture. 399-410

6. Dreifuss JJ, Tikhonov N (2007) Une etoile a la Belle Epoque: Lina Stern, professeur de medecine a Geneve. Rev Med Suisse 3(2306): 2308-2309

7. Liddelow SA (2011) Fluids and barriers of the CNS: a historical viewpoint. Fluids Barriers CNS 8:2

8. Wiesendanger M (2006) Constantin von Monakow (1853-1930): a pioneer in interdisciplinary brain research and a humanist. C R Biol 329:406-418

9. Davson H (2012) The blood-brain barrier. In: Bourne GH (ed) The structure and function of nervous tissue. Academic Press, London, pp 321-446

10. Stern L (1921) Le liquide céfalo-rachidien au point de vue de ses rapports avec la circulation sanguine et avec les éléments nerveux de l'axe cérébrospinal. Schweiz Arch Neurol Psychiatr 8:215-232

11. Stern L, Gautier R (1921) Recherches sur le liquide céphalorachidien. Arch Int Physiol 17:138-192

12. Stern L, Gautier R (1922) Recherches sur le liquide céphalorachidien. Les rapports entre le liquide céphalo-rachidien et les éléments nerveux de l'axe cérébrospinal. Arch Int Physiol 17: $391-448$

13. Stern L, Peyrot R (1927) Le fonctionnement de la barrière hématoencéphalique aux diverse stades de développement chez les diverses especes animals. C R Soc Biol (Paris) 96:1124-1126

14. Stern L, Rapoport JL (1928) Les rapports entre l'augmentation de la perméabilité de la barrière hémato-encéphalique et les altérations de son substratum morphologique. C R Soc Biol (Paris) 98:1515-1517

15. Stern L, Rapoport JL, Lokschina ES (1929) Le fonctionnement de la barrière hémato-encéphalique chez les nouveau nés. C R Soc Biol (Paris) 100:231-223

16. Grigorian NA (2017) Lina Solomonovna Stern (Shtern) 18781968. https://jwa.org/encyclopedia/article/stern-shtern-linasolomonova (accessed on 1 February 2017) 